\title{
NON-DESTRUCTIVE SURVEY OF ARCHAEOLOGICAL SITES USING AIRBORNE LASER SCANNING AND GEOPHYSICAL APPLICATIONS
}

\author{
Z. Poloprutskýa ${ }^{\mathrm{a},}$, M. Cejpová ${ }^{\mathrm{b}}$, J. Němcová $^{\mathrm{c}}$ \\ ${ }^{a}$ Faculty of Civil Engineering, CTU in Prague, Thákurova 7/2077, 16629 Prague 6, Czech Republic - \\ zdenek.poloprutsky@ fsv.cvut.cz

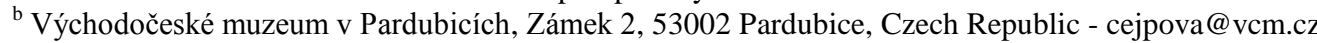 \\ ${ }^{c}$ Regionální muzeum v Litomyšli, Jiráskova 9, 57001 Litomyšl, Czech Republic - nemcova@ rml.cz
}

Commission V, WG V/2

KEY WORDS: Airborne laser scanning (ALS), Georadar (GPR), Radkov, Archaeological survey, Land survey mapping, Geographical information system (GIS), Georeferencing

\begin{abstract}
:
This paper deals with the non-destructive documentation of the "Radkov" (Svitavy district, Czech Republic) archaeological site. ALS, GPR and land survey mapping will be used for the analysis. The fortified hilltop settlement "Radkov" is an immovable historical monument with preserved relics of anthropogenic origin in relief. Terrain reconnaissance can identify several accentuated objects on site.

ALS enables identification of poorly recognizable archaeological objects and their contexture in the field. Geophysical survey enables defunct objects identification. These objects are hidden below the current ground surface and their layout is crucial. Land survey mapping provides technical support for ALS and GPR survey. It enables data georeferencing in geodetic reference systems. GIS can then be used for data analysis.

M. Cejpová and J. Němcová have studied this site over a long period of time. In 2012 Radkov was surveyed using ALS in the project "The Research of Ancient Road in Southwest Moravia and East Bohemia". Since 2015 the authors have been examining this site. This paper summarises the existing results of the work of these authors.

The digital elevation model in the form of a grid (GDEM) with a resolution $1 \mathrm{~m}$ of 2012 was the basis for this work. In 2015 the survey net, terrain reconnaissance and GPR survey of two archaeological objects were done at the site. GDEM was compared with these datasets. All datasets were processed individually and its results were compared in ArcGIS.

This work was supported by the Grant Agency of the CTU in Prague, grant No. SGS16/063/OHK1/1T/11.
\end{abstract}

\section{INTRODUCTION}

This paper deals with the non-destructive documentation of the "Radkov" (Svitavy district, Czech Republic) archaeological site. Airborne laser scanning (ALS), georadar (GPR) and land survey mapping will be used for the analysis. The fortified hilltop settlement "Radkov" is an immovable historical monument with preserved relics of anthropogenic origin in relief. Terrain reconnaissance can identify several accentuated objects on site.

M. Cejpová and J. Němcová have studied this site over a long period of time (Bolina et al., 2008; Cejpová, 2002; Cejpová and Němcová, 2007). In 2012 Radkov was surveyed using ALS in the NAKI (Applied Research and Development of National and Cultural Identity Programme) project "The Research of Ancient Road in Southwest Moravia and East Bohemia”(Martínek, 2014; Martínek et al., 2013). Since 2015 the authors have been examining this site. This paper summarises the existing results of the work of these authors. In the next chapter the planned works of authors are summarized and explained at the site.

The third chapter describes the processing of datasets in ArcGIS. The digital elevation model in the form of a grid (GDEM) with a resolution $1 \times 1 \mathrm{~m}$ of 2012 was the basis for this work. In 2015 the survey net, terrain reconnaissance and
GPR survey of two archaeological objects were done at the site. GDEM was compared with these datasets.

All datasets were processed into the geodatabase and the plan of the site at a map scale $1: 500$ in ArcGIS.

Corresponding author 


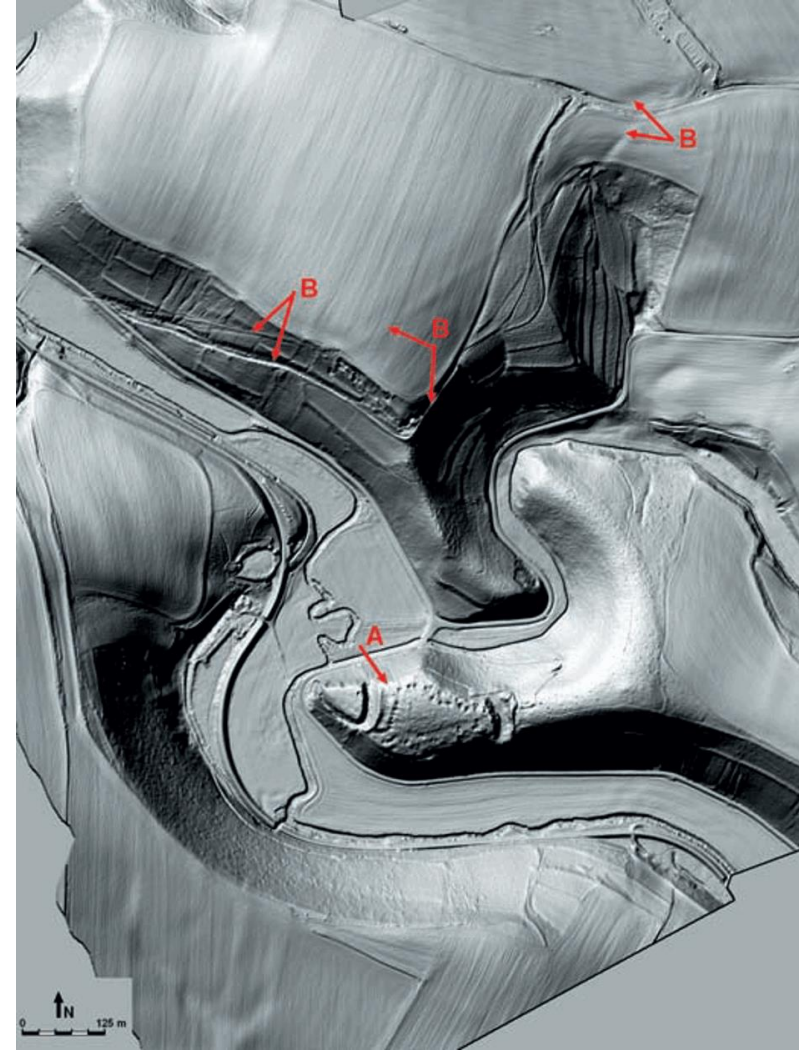

Figure 1. Radkov (A) on the historic route of the Moravian Třebová - Mohelnice /Líšnice (B).

\section{BENEFITS OF ARCHEOLOGICAL PROSPECTION}

This chapter describes the benefits which the combination of ALS, GPR survey and land survey mapping will be able to provide for archaeologists at the site Radkov.

\subsection{Site description}

Radkov is located on the promontory. It has two parts, which are separated by ramparts and moats from the promontory.

The eastern part, i.e. the greater part of the site, is fortified with the stone masonry wall on the probable access side. It is the only surviving masonry visible at the site. The eastern part of the site is further protected by two other ramparts and moats on the sides. The terrain slowly descends here from north to south. A lot of square to oval depressions are located at the periphery. Some have indications of the entrances of objects which define an area of "the square".

The western part of the site is triangular and plain with only a few modern disruptions. It is protected by a moat on the south-eastern and eastern side, and by rocky outcrops on the north-western side. The western side was damaged by a quarry.

The existing interpretations of the terrain relicts are based only on the surface prospection of the site. Written sources are not available. The subsurface archaeological research has not been undertaken at the site to date. Although rescue archaeological research was undertaken there in 2006, but it was limited to documenting a recessed object which was damaged by an unknown perpetrator. The over-ground part of the damaged object was made of stone and is likely to have been destroyed by fire (Cejpová and Němcová, 2007).

\subsection{Survey documentation}

Detailed terrain mapping, which displays the uneven terrain better than the terrain reconnaissance, enables better interpretation: distinction between nature - geology - humans.

The detailed survey of archaeological objects may influence the related dating of the site. In this case, it is the orientation of the objects, the entrances of objects, the number of rooms etc. In the existing literature Radkov is regarded as one of the typical large so-called colonization temporaries from the time of Boreš of Riesenburk, see Dlouhá Loučka, Třebovské hradisko, Hradisko u Radkova, which disappeared soon after due to historical circumstances, and thus have been preserved only in an embryonic form (Plaček, 1993).

Movable findings discovered during surface surveys of Radkov come from the 13th to 15th century and the early modern period, i.e. the 16 th century. These movable findings indicate a longer lifetime of the site. It is possible that the preserved recessed objects are not so-called colonizing temporaries but the basements of over-ground houses which were smaller than the over-ground parts of the building (Holub et al., 2005, 2003). The subject of interest is, therefore, the terrain following the recessed objects, as it may document the street line etc. The plan of the site is necessary for the admeasurement of boundaries of parcels etc.

Survey documentation connected to the coordinate reference system may enable the setting-out of the area for archaeological researches and the continuity of all archaeological research in the future.

\subsection{Comparison and evaluation of ALS details for terrain mapping}

The problem of this site is the absence of masonry relics in the terrain relics. Thus the surveyor has to extrapolate the terrain edges during the measurement process. Vegetation, e.g. blackberries, which overlaps minor terrain changes, makes the identifying of terrain edges in the forest more difficult (see Figure 4).

ALS should eliminate the subjective approach during the land survey mapping. The authors would, therefore, like to compare the digital elevation model of the ALS dataset and dataset from the land survey mapping using total station. The digital elevation model can be made from ALS dataset from the Czech Office for Surveying, Mapping and Cadastre (ČÚZK), from the NAKI project or from the dataset which was made by autonomous mapping airship (Koska, 2013), i.e. Remotely Piloted Aircraft System (RPAS). The authors would, therefore, like to find out for which field situation is the data set most appropriate. The authors assume that the ALS using the aircraft will be sufficient for the ramparts and moats, and the ALS using the airship will be sufficient for specific objects.

The land survey mapping using a total station enables the documentation of the terrain edges of objects, and ramparts and their schematic rendering by system of cuts. For the remains of house objects the shape of a star which comes out at the deepest point of an object or a series with a distance around $0.5 \mathrm{~m}$ can be selected. This land survey mapping will probably be very time consuming and laborious in the field.

Therefore we are interested in comparing the results of ALS using the airship with ALS measurements using the cuts, comparing the differences in the quality and whether the difference is proportional to the cost and the processing time. 


\section{DATASETS PROCESSING IN GIS}

This chapter describes the procedure for processing preprocessed datasets in ArcGIS step-by-step. The results are a geodatabase from analysed datasets and a plan of the site.

\subsection{Datasets}

In this step available dataset were gathered.

In 2002 the plan of the site which was surveyed at local coordinate system was made (see Figure 2). Its author is M. Cejpová (Cejpová, 2002).

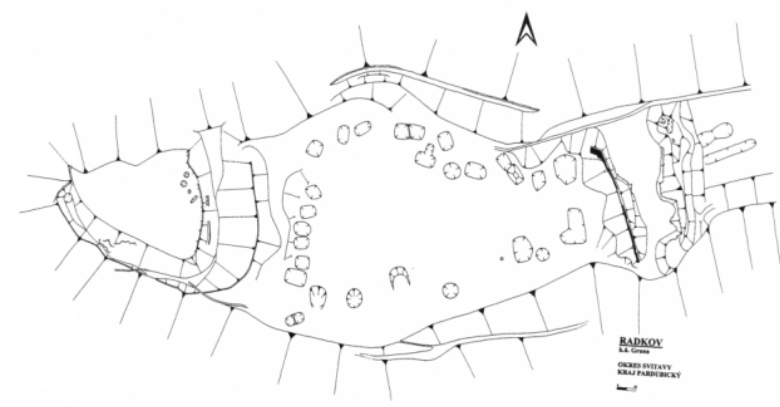

Figure 2. Radkov - plan of site, 2002

In 2012 a GDEM of the site which was based on ALS in the project "The Research of Ancient Road in Southwest Moravia and East Bohemia" was made (see Figure 3). This GDEM was surveyed in the geodetic reference systems, i.e. SJTSK (Datum of Uniform Trigonometric Cadastral Network) and Bpv (Baltic Vertical Datum - After Adjustment).

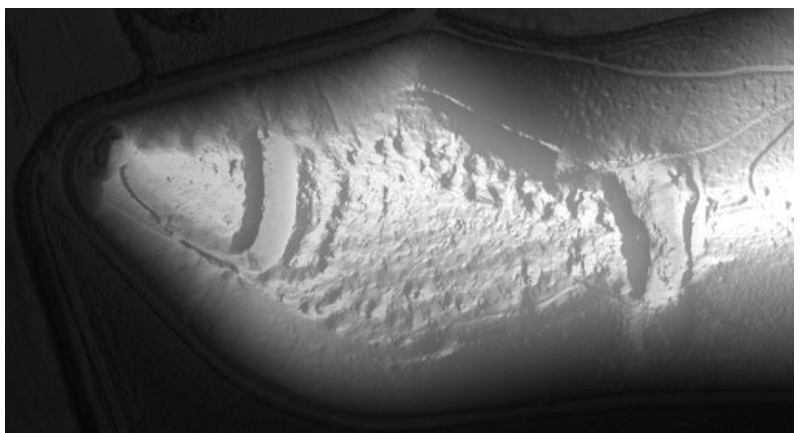

Figure 3. Radkov - GDEM, hillshade - Azimuth: $270^{\circ}$ and Altitude: $45^{\circ}, 2004$

In 2015 the survey net which was connected to the geodetic reference systems - S-JTSK and Bpv was made at the site (see Figure 4). Its authors are Z. Poloprutský and J. Hejduková.

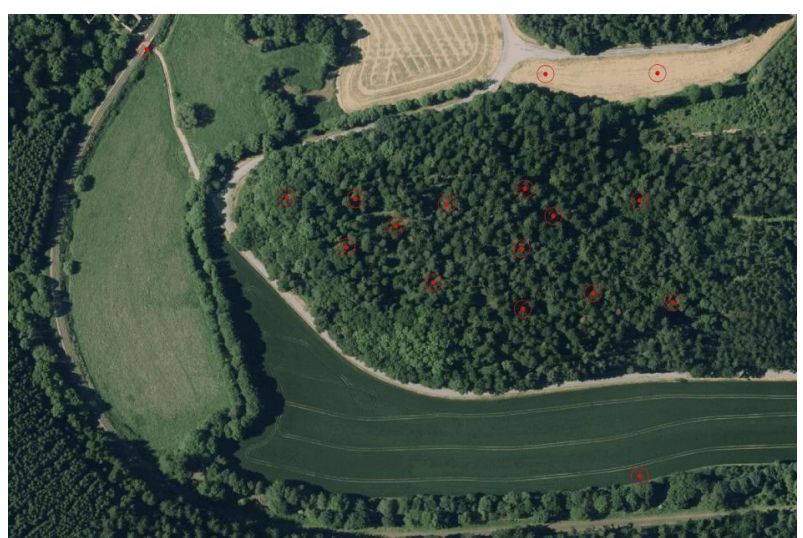

Figure 4. Radkov - survey net, 2015

In 2015 the GPR survey which was connected to the geodetic reference systems - S-JTSK and Bpv was realized at the site (see Figure 5). Its authors are Z. Poloprutský, M. Cejpová, J. Němcová and J. Hejduková.
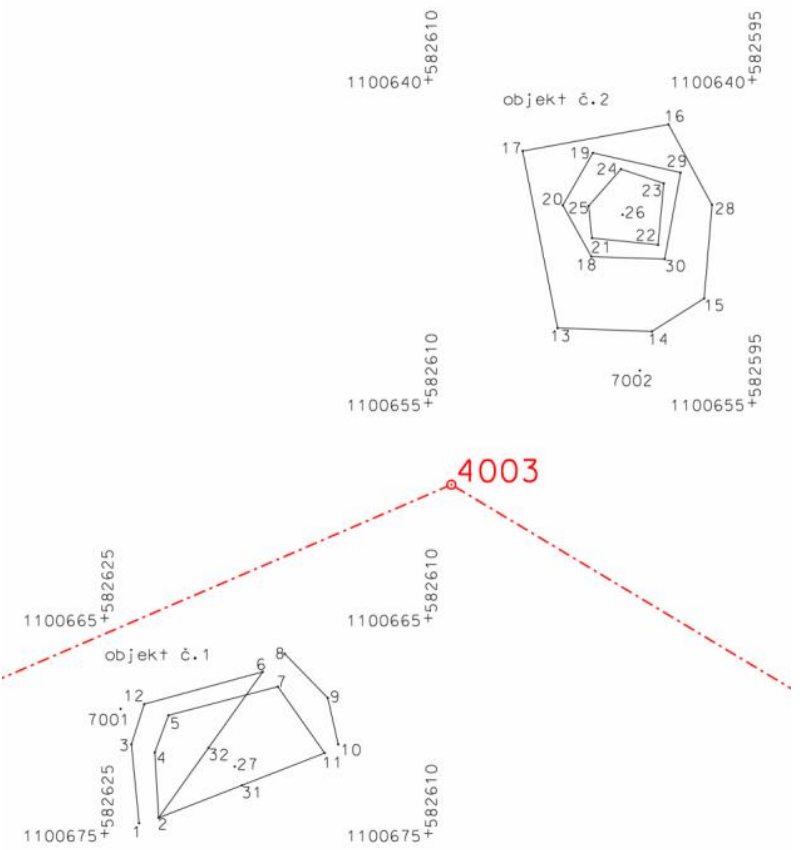

Figure 5. Radkov - profiles of GPR survey, 2015

\subsection{Editing of GDEM}

In this step the geodetic reference system of GDEM, i.e. SJTSK East-North (EPSG: 5514), was specified. GDEM was cropped to display the site of interest and was exported to the Shapefile - Point Features. Contour lines were interpolated at intervals $1 \mathrm{~m}$ and $5 \mathrm{~m}$ from GDEM.

\subsection{Elevation analysis}

In this step the elevations in the GDEM were compared with the elevations in the survey net. The time difference between the datasets is three years (see Table 6). Locations which have been farmed and field edges have a height difference of more than $|0.100 \mathrm{~m}|$. These height differences did not affect the accuracy of the final results. 


\begin{tabular}{|c|c|c|c|}
\hline $\mathbf{I D}$ & ${ }^{\mathbf{2 0 1 5}_{\mathbf{B}}} \mathbf{H}_{\text {Bpv }}[\mathbf{m}]$ & ${ }^{\mathbf{2 0 1 2}^{2}} \mathbf{H}_{\text {Bpv }}[\mathbf{m}]$ & $\boldsymbol{\Delta} \mathbf{H}_{\mathbf{B p v}}[\mathbf{m}]$ \\
\hline $\mathbf{( 1 )}$ & $\mathbf{( 2 )}$ & $\mathbf{( 3 )}$ & $\mathbf{( 4 )}=\mathbf{( 3 )}-\mathbf{( 2 )}$ \\
\hline 5001 & 332.510 & 332.291 & 0.219 \\
\hline 5002 & 330.730 & 330.607 & 0.123 \\
\hline 5003 & 332.374 & 331.917 & 0.457 \\
\hline 5004 & 326.698 & 326.716 & -0.018 \\
\hline 4001 & 363.808 & 363.752 & 0.056 \\
\hline 4002 & 362.797 & 362.763 & 0.034 \\
\hline 4003 & 361.488 & 361.469 & 0.019 \\
\hline 4004 & 357.209 & 357.167 & 0.042 \\
\hline 4005 & 355.468 & 355.414 & 0.054 \\
\hline 4006 & 359.242 & 359.245 & -0.003 \\
\hline 4007 & 357.245 & 356.699 & 0.546 \\
\hline 4008 & 355.384 & 355.421 & -0.037 \\
\hline 4009 & 352.699 & 352.670 & 0.029 \\
\hline 4010 & 362.416 & 362.361 & 0.055 \\
\hline 4011 & 359,228 & 359.183 & 0.045 \\
\hline 4012 & 360.341 & 360.334 & 0.007 \\
\hline 4013 & 358.666 & 358.642 & 0.024 \\
\hline
\end{tabular}

Table 6. Comparison of the elevations in survey net with the elevations in GDEM

\subsection{LMR - Local Relief Model}

In this step the LMR was made. The LRM represents local, small-scale elevation differences after removing the large-scale landscape forms from the data (Faltýnová et al., 2014; Hesse, 2010).

LRM has been created as the difference between the original GDEM and low-pass filtered GDEM. Different levels of lowpass filtering were tested (see Figure 7).

In the Figure 7 it is evident that the terrain relics of the archaeological objects were most pronounced for the lowpass filtering for $9 \times 9 \mathrm{~m}$. The low-pass filtering $7 \times 7 \mathrm{~m}$ exhibits noise in the LRM. Low-pass filterings $11 \times 11 \mathrm{~m}$ and $15 \times 15 \mathrm{~m}$ exhibit merging of the archaeological objects in the LRM.

GDEM was exported to the Shapefile - Point Features. Contours were interpolated at the value of $0 \mathrm{~m}$ and of negative interval $-10 \mathrm{~cm}$.

\subsection{Spatial analyses}

In this step the spatial analyses of the datasets which were based on LRM were made. The point interpretations of the terrain relics of the archaeological objects, i.e. objects and earthworks, were obtained by the combination of spatial and attribute queries (see Figure 8).

Spatial analyses were performed in two separate analyses:

1) The spatial analysis for objects:

a) spatial query: intersection of Point Feature based on LMR and contours with negative values, buffer $2 \mathrm{~m}$

b) attribute query: height difference $<=0 \mathrm{~m}$

2) The spatial analysis for objects:

a) spatial query: intersection of Point Feature based on LMR and contours with value: $0 \mathrm{~m}$, buffer $2 \mathrm{~m}$

b) attribute query: height difference $<=0.1 \mathrm{~m}$

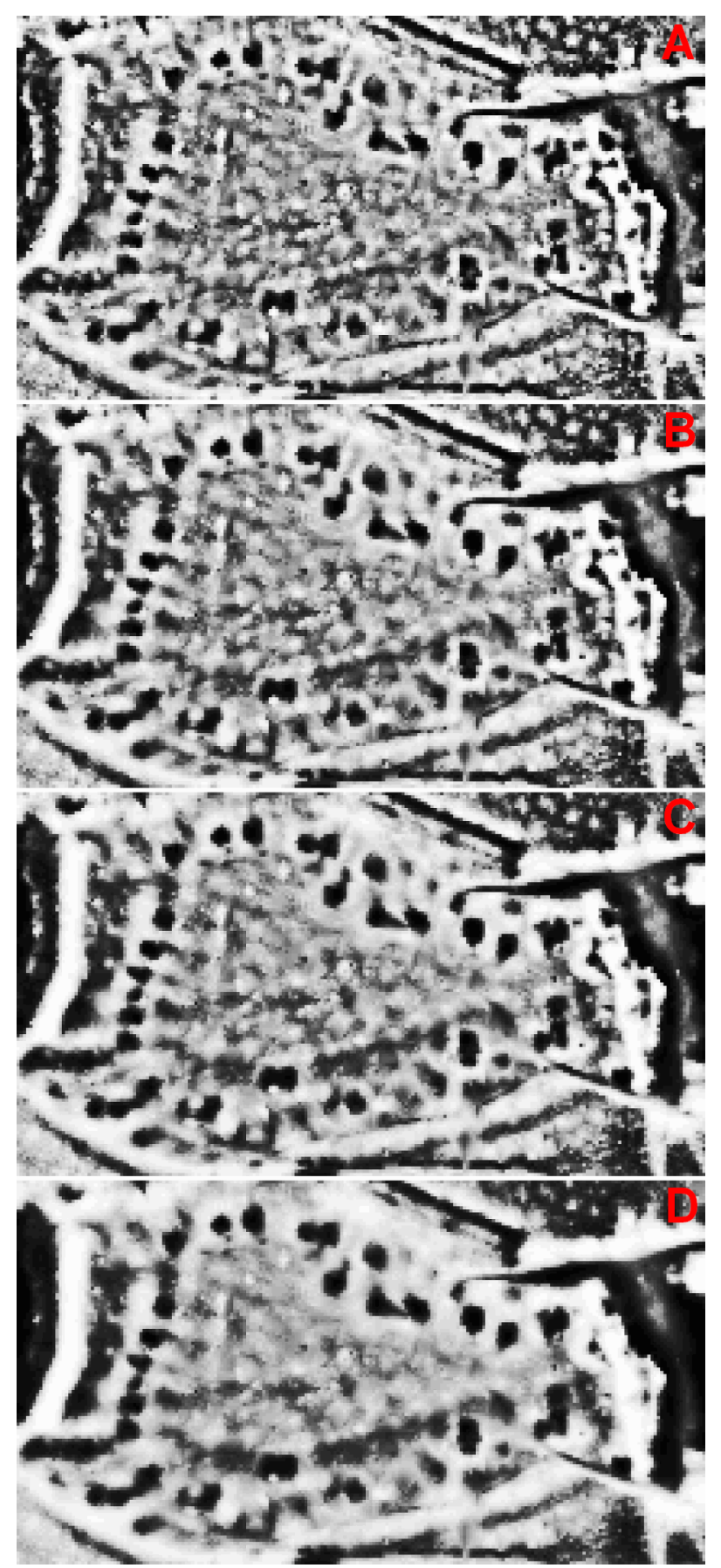

Figure 7. Radkov - profiles of GPR survey, 2015

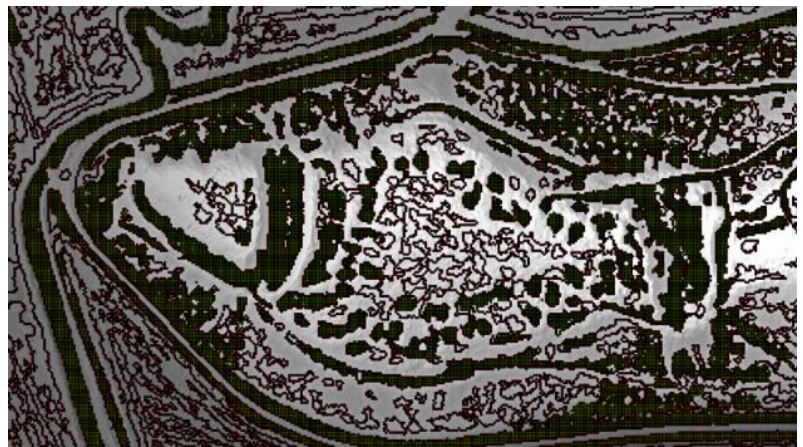

Figure 8. Radkov - point interpretations of the terrain relics of the archaeological objects 


\subsection{Vectorization}

In this step the manual selection of the point interpretations of the terrain relics of the archaeological objects and its vectorization to closed polygons were made (see Figure 9).

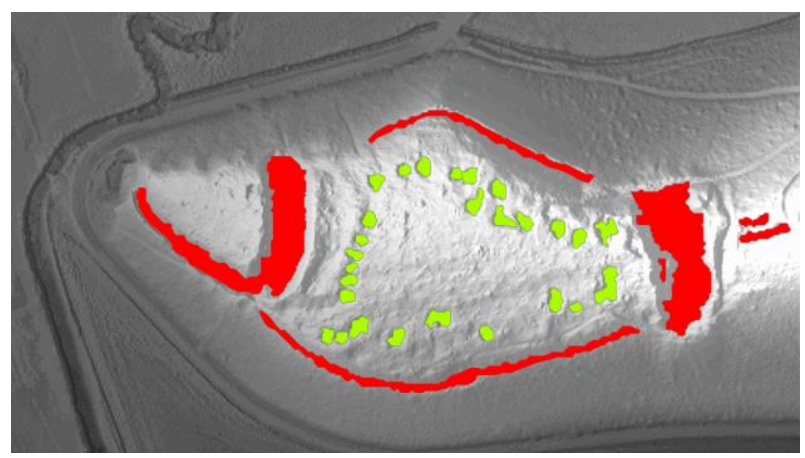

Figure 9. Radkov - vectorised terrain relics of the archaeological objects

\subsection{Geometry calculations}

In this step the geometric parameters of polygons were calculated, i.e. position coordinates of centroid, area and perimeter.

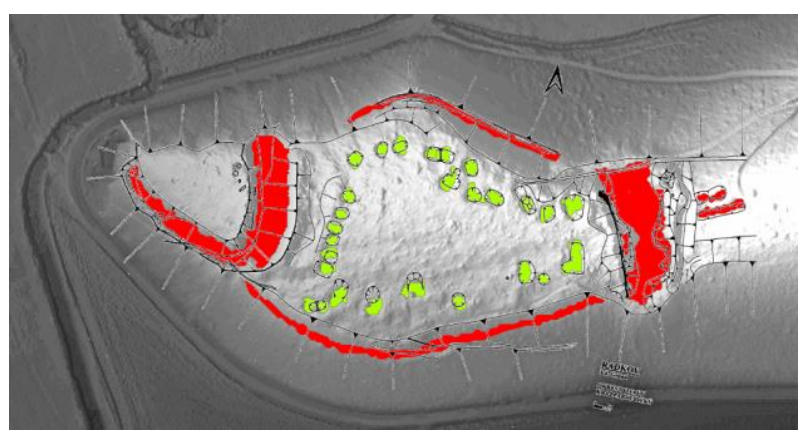

Figure 10. Radkov - georeferenced raster and polygons of the archaeological objects

\subsection{Georeferencing of the base map}

In this step, the dataset of 2004 was georeferenced (see Figure 10).

The affine transformation was used. The centroids of polygons of the archaeological objects were used as identical points. The georeferenced raster was visually inspected by the terrain edges in GDEM. Achieved RMS error is $1.48 \mathrm{~m}$.

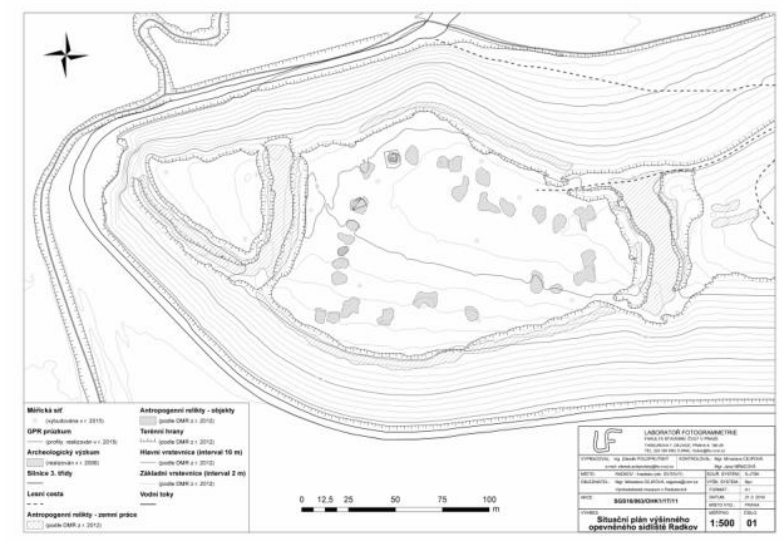

Figure 11. The plan of the fortified hilltop settlement "Radkov"

\subsection{Visualisation of the results}

In this step, the datasets were processed into a comprehensive geodatabase, which was visualized in the form of the plan of the site at the map scale $1: 500$ (Poloprutský, 2016).

\section{CONCLUSIONS}

This paper dealt with the use of combination of ALS, GPR survey and land survey mapping for non-destructive documentation of the archaeological site "Radkov" (Svitavy district, Czech Republic).

The final processing of datasets was implemented in a geographic information system ArcGIS. Datasets for this work were GDEM with a resolution 1x1 m from 2012, survey net at the site of interest from 2015 and geo-radar (GPR) survey of two selected archaeological objects.

By processing datasets in the GIS, it was found that:

1. The heights of the GDEM and the heights of the survey net match. Achieved deviations were for the purpose of this work negligible.

2. LRM captures the shape, dimensions and layout of terrain relics of anthropogenic origin in the area of interest. These are consistent with the plan of the site from 2004 and the terrain reconnaissance from 2015.

3. The plan of the site from 2004 can be georeferenced into a geodetic reference system S-JTSK East-North (EPSG: 5514).

4. GPR survey has helped identify areas at which archaeological research could be carried out in the future.

5. It was possible to visualize all the available datasets of the site at the map scale $1: 500$.

In the case of follow-up archaeological research in the fortified hilltop settlement "Radkov" the results of this study provide support for a proposed deployment of archaeological probes and their setting-out at the site of interest.

\section{ACKNOWLEDGEMENTS}

This work was supported by the Grant Agency of the Czech Technical University in Prague, grant No. SGS16/063/OHK1/1T/11.

\section{REFERENCES}

Bolina, P., Němcová, J., Šlézar, P., 2008. K počátkům hradů na Moravskotřebovsku. Castellologica bohemica 53-88.

Cejpová, M., 2002. Project PK99P04OPP029 - Castles, Strongholds and Redoubts in the Districts of Chrudim and Svitavy (1999-2002, MK0/PK). "The Research, Development and Innovation Information System of the Czech Republic." http://www.isvav.cz/projectDetail.do?rowId=PK99P04OPP029 (30. March 16).

Cejpová, M., Němcová, J., 2007. Záchranný archeologický výzkum na lokalitě Radkov u Gruny, In: Archeologické Výzkumy v Čechách 2006: Sborník Referátů Z Informačního Kolokvia. Česká archeologická společnost, Praha.

Faltýnová, M., Matoušková, E., Švec, Z., 2014. VISUALIZATION OF TRACKS USING DIGITAL TERRAIN MODEL AND IMAGE PROCESSING METHODS, In: 14th International Multidisciplinary Scientific Geoconference SGEM 
2014, Conference Proceedings. Presented at the SGEM 2014, STEF92 Technology Ltd., Sofia, pp. 405-410.

Hesse, R., 2010. LiDAR-derived Local Relief Models - a new tool for archaeological prospection. Archaeological Prospection 2012, 67-72.

Holub, P., Kolařík, P., Merta, D., Peška, M., Zapletalová, D., Zůbek, A., 2005. Ke stavu poznání nezděné měšt’anské architektury vrcholně středověkého Brna., In: Sbornik prispěvků $z$ konference FUMA konané 16.-18.4.2003, Forum Urbes Medii Aevi. Archaia Brno, Brno, pp. 44-101.

Holub, P., Merta, D., Peška, M., Zapletalová, D., Zůbek, A., 2003. K otázce topeništ' $v$ dřevohliněných domech ze 13 . století v Brně, ... aneb proč nevěŕme na zemnice, In: Sborník př́spěvků z 1. konference stavebně historického průzkumu 4. - 6. 6. $2002 v$ Zahrádkách u České Lipy Vývoj a funkce topeništ': věnováno památce Romana Kursy. Unicornis, Praha, pp. 75-84.

Koska, B., 2013. Autonomní mapovací vzducholod', In: 3D skenovaci systémy. České vysoké učení technické v Praze, Praha, pp. 325-340.

Martínek, J., 2014. Historické cesty. "Historické cesty: Projekt NAKI: Výzkum historických cest $\mathrm{v}$ oblasti severozápadní Moravy a východních Čech." http://www.historicke-cesty.cz/ (21. March 16).

Martínek, J., Létal, A., Peška, J., Kabálek, M., Vrána, J., Šlézar, P., 2013. The identification of past communication routes and other features using ALS: First results of an interdisciplinary project, In: Archaeology and airborne laser scanning of the landscape. Katedra archeologie, Západočeská univerzita $\mathrm{v}$ Plzni, Plzeň, pp. 228-240.

Plaček, M., 1993. Povrchový průzkum reliéfních zbytků několika opevněných sídel v Boskovické brázdě, In: Přehled Výzkumů 1990. Archeologický ústav AV ČR, Brno, pp. 105107.

Poloprutský, Z., 2016. The plan of the fortified hilltop settlement Radkov. "Specialized map with expert content" http://lfgm.fsv.cvut.cz/main.php?cap=0\&zal=475\&lang=en (23.March 2016). 